\title{
BY THE POWER OF SNS, WE CAN... AND YET...ACTIVISM THROUGH SNS: POTENTIAL AND LIMITATIONS IN TURKEY
}

\author{
Şenay Yavuz GÖRKEM \\ Maltepe University, Turkey \\ senayyavuz@,maltepe.edu.tr
}

\begin{abstract}
This research article summarizes the findings of a larger research study which attempted to gather data on Turkish activists' perceptions on the scope, strength andlimitations of digital activism. Qualitative data were collected via a web-based survey from 302 activists to find out what potential and limitations Turkish activists attribute to utilization of SNS for activism purposes. The results illustrated that a total of 263 activists in the sampleappreciated SNS for providing a fertile ground for activism and a total of 131 activists drew attention to the potential of SNS for managerial purposes, for awareness raising and forcreating positive publicity for the cause and the activists. The role of SNS for themaintenance of polyvocality was expressed by a total of 115 activists. The political environment, surveillance, control and manipulation of the internet, disbelief in jurisdiction, the fear atmosphere and the social environment were the limitations selfreported by theactivists in the sample.
\end{abstract}

Keywords: Digital activism, SNS, potential, limitations, Gezi

\section{SOSYAL PAYLAŞIM SITELERININ GÜCÜ ADINA BAŞARABİLİRIZ; FAKAT...TÜRKIYYE'DE SOSYAL PAYLAȘIM SITELERİ ÜZERINDEN YÜRÜTÜLEN AKTIVIZMIN POTANSIYYELI VE SINIRLILIKLARI}

\begin{abstract}
ÖZ
Bu makale, Türk aktivistlerin dijital aktivizmin kapsamı, gücü ve sınırlılıkları ile ilgili algıları üzerine veri toplamayı amaçlayan kapsamlı bir çalışmanın sonuçlarının bir kısmını özetlemektedir. Türk aktivistlerin sosyal paylaşım sitelerinin aktivizm amaçlı kullanımına hangi potansiyel ve sinırlılıkları atfettiğini bulmak amacıyla 302 aktivisten internet üzerinden oluşturulmuş bir anketle nitel veri toplanıldı. Sonuçlar, 263 aktivistin sosyal paylaşım sitelerinin aktivizm için verimli bir ortam yarattığını ve bu bağlamda sosyal paylaşım sitelerini değerli bulduğunu ve 131 aktivistin sosyal paylaşım sitelerinin dijital aktivizm eylemleri sırasında yönetimsel fonksiyonlar amaciyla kullanımı, bilinçlendirme ve dava ve aktivistlerle ilgili olumlu imaj yaratma konularındaki potansiyeline dikkat çektiğini göstermiştir. Sosyal paylaşım sitelerinin çoksesliliğin sağlanması konusundaki rolü 115 aktivist tarafindan ifade edildi. Siyasi ortam, denetim, internetin kontrolü ve manipülasyonu, yargıya olan güvensizlik, korku atmosferi ve sosyal ortam bu çalışmanın örnekleminde bulunan aktivistler tarafından belirtilen sinırlılıklardı.
\end{abstract}

Anahtar Kelimeler: Dijital aktivism, sosyal paylaşım siteleri, potansiyel, sinırlılıklar, Gezi

\section{INTRODUCTION}

Advances in information technologies have accelerated and enhanced the global flow of ideology, information and opinion; each and every individual now has the opportunity to become an active agent in the process of information and opinion flow. The user centered structure of the internet has enabled individuals to become more autonomous and given birth to a new form of communication, which Castells calls 'personal mass communication'. Individuals can now share information without facing any limitations exposed by gatekeepers; they also select and attend to a variety of information 
that is available online. In other words, the control of information flow has got out of the hands of power elites and the mass media, which could act under the influence of these power elites at times. Internet 2.0. has reshaped power relations in modern societies by enabling people to unite in networked thinking systems and act online and offline (Castells, 2009). Social networking sites (SNS) became instrumental in this respect due to their popularity among the youth and their nature, which makes it convenient for individuals to reach and communicate with other people with the same concerns and causes.

The civic and democratic potential of the internet and SNS has been a matter of debate for long. The representatives of the optimistic perspective (Castells, 2009; Shirky, 2008) assert that information technologies break down power relations, empower individuals, enable greater interactivity, create new means of political participation and even replace traditional forms of activism. The pessimists (Putnam 2000; Schulman, 2009; Morozov, 2009), on the other hand, highlight the idea that digital activism does not always lead to or is not always accompanied by offline forms of activism. According to the pessimists, digital activism serves to increase the activists' 'feel good factor' without getting involved in any kind of physical action and as it is the physical action that can cause real social or political change, digital activism acts as a barrier for activism. That is why they use the terms 'clicktivism', 'one click activism', 'armchair activism' and 'slacktivism' for digital activism. According to the pessimistic perspective, digital activism pacifies a great potential by giving activists a fake feeling that they did something.

However, literature on digital activism does not suggest that digital activism is not an effort without any positive effects in the offline sphere. Research shows that individuals' online and offline political participation are related, which indicates that it would be wrong to consider online activism efforts as detached from offline tendencies and activities (Christensen, 2012, Štětka \& Mazák, 2014). Research also illustrates that digital activism has a positive effect on offline mobilization (Christensen, 2011). Recent instances of digital activism and reports of activists; for example the ones who were active during the Arab Spring, illustrated that digital activism could be used to support traditional activism and enhance communication and coordination (Baraković, 2011, Gerbaudo, 2012). However, it is a fact that digital activism efforts are carried out under different circumstances by different activist groups. There are situational factors that affect and limit digital activism efforts in any country. The cross-cultural study by Harp, Bachmann and Guo (2012), for instance, showed that the main limitation that Chinese activists faced was the fear of government surveillance while the top challenge for American activists was lack of time. In the same study, Brazilian activists pointed to the lack of access to affordable internet as the most significant obstacle they had to overcome, which demonstrated that economy in a country can make a difference in digital activism efforts.

This study moves in this direction and aims to find out what purposes social networking sites such as Facebook, Twitter or YouTube serve for digital activism according to Turkish activists and Turkish activists' perceptions on the limitations of digital activism in Turkey. The following section summarizes the related literature. The first part focuses on the internet and activism and elaborates on how advances in information technologies have transformed activism efforts. The following subsection focuses on SNS and their role in digital activism efforts.

\section{LITERATURE REVIEW}

\section{THE INTERNET AND ACTIVISM}

Digital technologies enable people to interact without any spatial or temporal limitations and offer a rich source of information to anyone with access to the internet (Shah, 2013). The internet has changed the building blocks of information sharing and created a world in which information flow cannot be controlled but instead follows a chaotic pattern with numerous active agents making concurrent contributions to the existing archive of information. Information cannot be undisclosed for long due to the principle of transparency, civil demand for information sharing and increased ability of individuals to access information as compared to the past. The statement 'Real total war has become information war.' points to the power of information in contemporary societies (Lunceford, 
2012, p. 51). It should be noted here that digital technologies have empowered individuals in the information war and provided activists with new tools through which they can voice their opinions.

The internet acts as a channel for alternative discourse, supports polyvocality and enhances opinion sharing. Habermasian 'public spheres' in which people come together and voice their opinions informally and freely have been criticized for years due to their lack of ability to include people from all segments and locations of the society. Only members of the middle class whose presence in such meetings were considered as accepted behavior in the society could be a part of the public spheres created in their neighborhoods and the other members of the society were excluded from these public spheres, which decreased the public spheres' ability to reflect the views of the public. In contrast, with the help of the internet and social media sites, individuals can create numerous 'virtual public spheres' without facing any geographical, cultural or socioeconomic obstacles and voice their opinions freely now (Harp, Bachmann \& Guo, 2012, p. 299). It cannot be denied that one needs digital tools and access to the internet in order to join these virtual public spheres. However, as current statistics show almost three billion people on earth have access to the internet (http://www. Internet worldstats.com/stats.htm) and thus it would not be wrong to conclude that more virtual public spheres exist virtually than they do in reality.

The sheer number of people following current events online led to the emergence of the term e-public opinion (Baraković, 2011, p. 196). While it gets less and less convenient for people to come together and share their ideas offline due to their tight daily schedules, more and more people tend to access social media and thus different opinions with their ubiquitous mobile phones or computers. Opinion flow and discussions in social media influence e-public opinion and e-public opinion has the potential to affect the offline public opinion. The agenda and e-public opinion created online can also affect mass media as the mass media cannot ignore online events, especially if they have an impact on the offline world.

Dissident opinions can be expressed online and communication can transcend national borders easily (Newsom \& Lengel, 2012, p. 33). Social networking sites make it more convenient for people to search for and reach other individuals who share common interests and causes with themselves as compared to the past (Micó \& Ripollés, 2014, p. 861; Newsom \& Lengel, 2012, p. 32). In other words, social networking sites help people form 'ideologic friendships' (Şener, 2014, p. 192). That's why, online societies are created and the members of these societies feel empowered by the high number of people who share their ideologies and causes. These online societies created together with collective identities act as critical powers.

The internet has also increased participation to political activism as it has made it more convenient and less costly to be an activist. Nowadays individuals can contribute to political activism without leaving their homes, changing their daily schedules and making much physical effort. They also do not need to face any physical risks (Lunceford, 2012, p. 42-43). This situation might explain why some studies show that many individuals, who have never been involved in offline activism, contribute to online political activism (Micó \& Ripollés, 2014, p. 860-861). Digital technologies enable people to unite and create social or political effect without coming together physically (Boykoff, 2012, p. 486). Digital technologies lower the threshold for political action (Bakardjieva, Svensson \& Skoric, 2012, p. 1).

The internet emancipates individuals living in oppressive regimes as well. Individuals can communicate with each other by using encryption and anonymous communication software which can resist surveillance. Programs which are useful in staying anonymous and hiding identities enable individuals to minimize the risk they might have to face in case their online activities are detected. Sheer quantity of information flow on the internet also helps online activists as it makes it almost impossible for governments to monitor all information flow and detect dissident action online (Murdoch, 2010, p. 142). 


\section{SNS AND DIGITAL ACTIVISM}

Due to advances in digital technologies and in synchrony with the creativity of activists, repertoire of digital activism is enlarging day by day. Some of the tactics included in the array of digital activism are using e-mails for organizational tasks (Banks, 2014, p. 27), using blogs to inform people, raise awareness and get public support (Ghannam, 2011, p. 5) and utilization of internet sites, which are specifically set up for activism purposes, to share contemporary information that the mass media ignores and react to current events (Banks, 2014, p. 27). DoS (Denial of Service Attacks) organized by hackers also serve activism purposes. Programs that make thousands of requests simultaneously from a web site and cause the server to slow down and sometimes crash are used to attack corporations or governments with the aim of protesting them (Norman, 2001, p. 250). Castells calls these attacks 'information guerilla movements (Şener, 2014, p. 185). DoS attacks are also called 'virtual sit-ins' (Muhammad, 2001, p. 74). Another digital activism tactic executed by hackers is web site defacements. Individuals hack into a server hosting a web site and alter its content to attack opposing parties and voice their opinions (Murdoch, 2010, p. 141). Use of SNS, which enable their users to share messages with multimedia content easily with numerous people within seconds, is yet another online activism tactic. (Amin, 2009-2010, p. 65). In fact, results of a survey study conducted with a sample of 122 international activists in 2009 showed that the use of SNS was the most frequently utilized tactic.

Research has shown that SNS are utilized for various activism purposes by activist groups. For instance, a cross-cultural research study, which was based on data gathered from 456 activists in China, Latin America and the United States, illustrated that SNS were used for managerial purposes such as sending information to followers or planning and mobilizing purposes such as creating online groups and increasing participation to an event as well as communication and awareness purposes (Harp, Bachmann \& Guo, 2012, pp. 302, 310). Research also demonstrated that SNS are utilized to attract new members or local support, to distribute petitions for others to sign, to fundraise, to mobilize offline and online supporters, to promote debate or discussion, to put pressure on political elites and to communicate with journalists (Harlow \& Harp, 2012, p. 205).

Sharing visuals and videos that aim to alter the knowledge, attitudes and behaviors of the recipients about political events and protests though social networking sites is also a common practice. These visuals or videos are usually humorous since humorous content is more popular online. As Ethan Zuckerman asserts in his 'cute cat theory of social media' people prefer short humorous content to long, political content (Gerbaudo, 2012, p. 148). Some visuals and videos are used to cultivate hatred towards a political figure in the society and get support for the protests. Disproportionate violence used by police forces of governments against protestors or civilians are recorded and shared for this purpose. In our era of visual hegemony, it should be stated that use of visuals serve a very significant role as visuals can tell what pages of plain text cannot and as people prefer spending time on visuals, not long texts when they are online. There is no doubt that SNS are very effective mediums to make sure that these visuals and videos are seen by masses.

SNS are also used to announce celebrity endorsement for the cause of the protest as well. The support given by celebrities and international organizations to a protest is announced online and emphasized again and again by different individuals. This can be considered as a kind of celebrity endorsement for the cause of the protests. For instance, support provided by celebrities such as Noam Chomsky, Slajov Zizek, Paulo Coelho, Roger Walters, Madonna, Suzan Sarandon, international organizations such as Greenpeace and Amnesty International and many Turkish celebrities to Gezi protests were announced through social media to persuade the public to provide support for the protests.

Protestors disseminate information about opposing parties through social media in order to discredit them and to get an edge over them in terms of gaining public support, too (Murdoch, 2010, p. 139). This sharing of information and/or misinformation about the targets of protests can also aim to create attitude change or hatred towards the opponent parties. For instance, after corruption and bribery news with political dimension broke on November 17, 2013 in Turkey, voice recordings involving ministers, their descendants, the prime minister, prime minister's descendants and businessmen 
started to be shared on Twitter by an account named 'Haramzadeler' (The Unscrupulous) with some intervals. People, especially the activists involved in Gezi protests were waiting for new recordings every day with appetite. Although the report by The Scientific and Technological Research Council of Turkey stated that the recordings were fake, the activists managed to bring many politicians into disrepute.

Şener (2014, p. 186), claims that social media strengthens the culture of resistance. Self-reports of activists reflecting their perceptions related to digital activism supports this claim. The following statements of Ahmed Samih, an Egyptian activist summarizes the use of SNS (Gerbaudo, 2012, p. 136):

The only new thing about these tools is that you are not a member in an organization anymore; you are a member in a cause or a movement. And you do not need to have physical membership. You do not need to go to the meeting. You are not organizing things underground anymore. You do everything over the internet. So you get the instructions... and if the instructions are convincing you, you yourself start to play a little bit of a part. You start to tell your friends, your family. You know what the goal is, which is to spread the information, and you start to give it to people. You start to create from the tools you have. You start to spread the information by word-of-mouth as much as you can. You send text messages to all your contacts. You send your people emails. You communicate with colleagues at work.

According to another Egyptian activist, Facebook was used to set the date, Twitter was used to share the logistics, YouTube was used to show the events to the world and all of these sites were used to connect people during the Arab Spring (Gerbaudo, 2012, p. 3). In some cases, protestors set up their own social networking sites. The social networking site named N-1 during the Spanish Revolution in 2011 is an example to this practice (Micó \& Ripollés, 2014, p. 858). Social networking sites have a snowball effect on information. A text, visual or video shared by one individual is augmented in content and reach as more and more people read, comment on and share it.

Research shows that perceived ease of use and perceived usefulness significantly affects individuals' intention to use SNS for activism purposes (Borrero et. al., 2014). The study by Harlow and Harp (2012, p. 207-208) showed that activists from the United States and Latin America self-report that SNS play an important part in social movements, contribute to a public dialogue about matters of interest to them and that SNS made them more politically and civically active. This study also illustrated that activists acknowledge the ability of SNS to cross distances and time barriers to create communities, mobilize people for offline activism, reach a mass of potential supporters and raise awareness. A qualitative study of environmental activism through SNS in Scotland confirmed these findings and highlighted the use of SNS for the purposes of extending and accelerating the circulation of information, mobilizing resources, raising awareness, facilitating discussion, organizing events, gaining public attention and developing horizontal networks. The study also highlighted that activists perceived SNS as effective means for creating user friendly and flexible forms of communication as well as a means of acquiring a sense of belonging to a community (Hemmi \& Crowther, 2013, p. 2). This research study moves within this framework and aims to reveal Turkish activists' perceptions relating to the potential and limitations of SNS for digital activism due to the fact that Turkish society has been politically and socially polarized for a decade and the tension created between these polarized groups has led to cases of both offline and online activism. In contrast with this fact, little is known about the perceptions of Turkish activists relating to potential and limitations of SNS although they are frequently utilized tools. The results in this research study are part of a larger study that focused on the scope and strength of digital activism in Turkey. Data revealed in this study have the potential to shed light to Turkish activists' future use of SNS for activism purposes considering the relation between perceived ease of use, perceived usefulness and intention to use SNS for activism purposes. This study is also of significance for its contribution to cross-cultural data regarding potential and limitations of SNS for activism purposes in different cultures as it is the cultural realities and norms that set the limits to activism efforts and shape tendencies. The research questions asked are: 
RQ1: What functions do social networking sites serve for activism purposes according to Turkish activists?

RQ2: What are the limitations of digital activism according to Turkish activists?

\section{METHODS}

A web-based survey was prepared and used for the purposes of this study. The survey included items that focused on the socio-demographic profile of the respondents in a closed-ended format. The second part of the survey consisted of three open-ended questions. The questions asked were: 1 . What do you think are the contributions of digital technologies to the culture of activism? 2. Why are the social networking sites such as Facebook, Twitter and YouTube used for activism purposes according to you? 3. Do you think that there are factors that impede digital activism in Turkey according to you? If yes, please list the impeding factors. The survey was prepared in Turkish and data were collected between April $1^{\text {st }}$ and May $31^{\text {st }}$ 2015. The answers were than translated into English by the researcher, who has an MA degree in applied linguistics. As the survey was on digital activism and the aim was to reach people who engage in digital activism, online data collection method was utilized.

\section{SAMPLE}

Purposeful sampling method was used and large online communities with activism backgrounds were included in the universe of the study considering the desired profile of the respondents. The online groups chosen were RedHack, Taksim Solidarity, OccupyGezi, Spirit of Gezi, Çarşı, Middle East Technical University and followers of Fuat Avni. Representatives of traditional activism were also included in the sample of the study with the hope that the perceptions of traditional activists will help achieve a balanced view. Members of Confederation of Progressive Trade Unions of Turkey (DISK), Confederation of Public Worker's Union (KESK) and Education and Science Workers' Union (Eğitim-Sen) were invited to fill in the survey. The caricaturists of a famous humor magazine were also included in the universe of the study as humor has been a means for the expression of political and social dissent in Turkey for decades. It should be stated here that many of these online communities have hundreds of thousands of members. Respondents were asked to forward the survey to other activists for a snowball effect and to increase the sample size in an efficient way. A total of 302 activists responded to the survey. Demographics of the sample are summarized below.

Table 1. Demographics of the Sample $(\mathrm{N}=302)$

\begin{tabular}{|l|l|l|l|}
\hline Variable & Group & \multicolumn{1}{|c|}{ f } & \% \\
\hline Age & $18-29$ & 76 & 25,2 \\
\hline & $30-39$ & 113 & 37,4 \\
\hline & $40-49$ & 69 & 22,8 \\
\hline & 50 and above & 41 & 13,6 \\
\hline Gender & Missing & 3 & 1,0 \\
\hline & Women & 172 & 57,0 \\
\hline & Men & 128 & 42,4 \\
\hline Marital Status & Missing & 2 &, 7 \\
\hline & Single & 155 & 51,3 \\
\hline & Married & 141 & 46,7 \\
\hline Educational Background & Missing & 6 & 2,0 \\
\hline & Primary Education & 0 & 0 \\
\hline & Secondary Education & 1 &, 3 \\
\hline & High School Education & 26 & 8,6 \\
\hline & Associate Degree & 24 & 7,9 \\
\hline & Bachelor's Degree & 145 & 48,0 \\
\hline & Master's Degree & 76 & 25,2 \\
\hline Digital Competency & Doctorate Degree & 26 & 8,6 \\
\hline & Very Incompetent & 1 &, 3 \\
\hline
\end{tabular}




\begin{tabular}{|l|l|l|l|}
\hline & Incompetent & 11 & 3,6 \\
\hline & Moderate & 77 & 25,5 \\
\hline & Competent & 149 & 49,3 \\
\hline & Very Competent & 61 & 20,2 \\
\hline & Missing & 3 & 1,0 \\
\hline
\end{tabular}

As can be seen in Table 1, majority of the activists that responded to the survey were young. Over 62 $\%$ were aged between 18 and 39 years. Just below $23 \%$ of the sample was in their forties. A very low percentage of the activists was 50 or above. The percentage of single people was slightly higher than the percentage of married people. Almost three fourth of the respondents $(73,2 \%)$ had a BA or a higher degree. Almost $70 \%$ of the respondents indicated that they felt competent in using digital technologies and $25,5 \%$ reported their competency as moderate.

\section{ANALYSIS}

Descriptive statistics for socio-demographic factors were calculated by using Statistical Package for Social Sciences (SPSS) 20. In order to gain insight into Turkish activists' perceptions on potentials and limitations of SNS participants' answers to three open-ended questions (1. What do you think are the contributions of digital technologies to the culture of activism? 2. Why are the social networking sites such as Facebook, Twitter and YouTube used for activism purposes according to you? 3. Do you think that there are factors that impede digital activism in Turkey according to you? If yes, please list the impeding factors) were analyzed inductively in content. The written comments of the respondents were categorized on the basis of similarity in content (Cho \& Lee, 2014). The researcher did not have any pre-determined categories; the categories emerged as data was processed.

\section{RESULTS}

As to RQ1, a total of 263 activists laid emphasis on the inherent nature of digital technologies and how this nature provided a fertile ground that enhanced activism. The contention that ideologies that are named as 'marginal' by political forces can be introduced to masses of people who would be impossible to reach otherwise due to the high popularity of digital technologies and social networking sites among people, especially the young, was expressed by the activists. How digital technologies, especially the social networking sites made easy, fast and safe communication and correspondence possible was also consistently voiced by the activists. Convenience was another attribute to digital activism; activists argued that it is hard to contribute to offline activism for many reasons such as physical distances, lack of time, physical disabilities, agedness, illnesses, walking difficulties, drug use or personal preferences and that people prefer digital activism because it is more convenient and practical. Another line of comments praised that social networking sites are very easy to access and this cheap, easy and fast access contributes to activism efforts. Interactive nature of social networking sites, which provides activists with opportunities to meet people who think like them and come together for social issues that can only be solved in unity, was also expressed by the activists in the sample of the present research. How the inherent characteristics of the internet and social networking sites contributed and enhanced digital activism efforts was expressed by an activist as follows:

Its interactive and transparent nature triggers individuals' creativity and creates a less centralized but more participative environment.

These inherent characteristics of the internet and social networking sites were praised not only by Turkish activists but by activists from other cultures as aforementioned in the literature review. Potential of digital technologies for communication, correspondence and informing others were reported by activists from China, Egypt, Latin America, United States and Scotland (Ghannam, 2011, p. 5; Gerbaudo, 2012, p. 3; Harp, Bachmann \& Guo, 2012, pp. 302, 310; Hemmi \& Crowther, 2013, p. 2; Banks, 2014, p.27). Convenience of digital activism and the fact that they can be accessed and used easily were also pointed out by activists from other cultures; e.g. by Egyptian and Scottish activists (Gerbaudo, 2012, p. 136; Hemmi \& Crowther, 2013, p. 2). Potential of digital technologies 
for reaching a mass of potential supporters, their interactive nature and how this interactive nature helps create online communities that act together to solve social issues were asserted by activists from other cultures as well (Ghannam, 2011; Gerbaudo, 2012; Harlow \& Harp, 2012; Harp, Bachmann \& Guo, 2012; Hemmi \& Crowther, 2013 ).

However, self-reports of Turkish activists showed that Turkish activists appreciated these inherent characteristics and highlighted the role they played in the maintenance of polyvocality by providing marginalized voices with a safe tool for free expression remarkably and differed from activists from other cultures in this respect. A total of 115 comments centered on this issue. These activists criticized situational factors in Turkey and emphasized how social networking sites were used as a remedy. Activists expressed concerns about the political, legal and social factors which limited Turkish people's right to freedom of speech and expression and positioned social networking sites as tools with liberating effects. Turkish media was portrayed by the activists as far from reality, bootlicker, bourgeois, coward and as one that serves the governments' interests but does not hear the voice of millions or let dissident people express their opinions. This criticism of the mass media reflects activists' discontent with the role that the media plays in the transformative period that Turkey is going through. A "new Turkey" is being created as the former Prime Minister, current President Recep Tayyip Erdoğan states, which causes anxiety in almost half of the population as they perceive the country as being dragged into a fundamentalist abyss (Akgül \& Kırlıdoğ, 2015, p. 12). The 'new' media seems to be lost in a spiral of silence during this transformative period.

It is impossible to argue that media is completely independent, unbiased and stands from particular interests in any part of world, even in western countries where democracy is claimed to be well established. The only difference is that censor in these countries is practiced in a more self-driven and subtle way. However, the current Turkish media not only tends to serve its interests and the governments' but also suppress all dissident opinions. There are many reasons for this. Newsmakers in Turkey experience different kinds of neoliberal government pressures and this pressure has been increasing in volume since 2007. Turkish journalists and the public witnessed that one of the most powerful media conglomerates, Uzan group whose CEO was Cem Uzan, who was critical of Justice and Development Party (AKP) and targeted Recep Tayyip Erdoğan in every public speech he made, were seized by the Savings Deposit Insurance Fund and sold to international companies or national groups that were friendly to the government in 2008. This specific case told all other media conglomerates and media bosses that the government can impose fines over taxes on media groups when they become critical of the government and topple media conglomerates. It is not claimed here that the economic measures that are taken against media conglomerates by the government are illegal; however, it is interesting that they are enforced when these companies become critical of the government (Akser \& Baybars-Hawks, 2012; pp 307-308). Doğan group, which controlled almost half of all the print, audio-visual and new media in Turkey went through a similar crisis after they covered a court case that took place in Germany on the misuse of donations to Lighthouse Foundation, an NGO in Germany, and questioned the governments' involvement in the fraud. Erdoğan accused the media group of fraud and with being biased and invited the public to boycott Doğan Media (Akser \& Baybars-Hawks, 2012; pp 307-308). Although it was interesting to see that Doğan Media Group, which has always advocated the governments' practices, became critical only after they could not get the approval for a refinery in Ceyhan (a coastal town at the crossroads of a petroleum pipelines) from the government, the consequences of this dispute taught the media and the public once again that the government had the power to cause changes in the media (Kaya \&Çakmur, 2010 , p. 532). Timing of this dispute pointed to the fact that almost all media holdings in Turkey are parts of large conglomerates with major economic interests in other sectors and as only a minor percentage of their profits come from the media sector they become dependent on government favor especially during times of economic booming and privatization in order to maintain good relations with the government and partake in potential opportunities. Aydın Doğan, the CEO of the group, had to fire columnists, close a critical newspaper, resign as CEO of the company and yet was sued for 2.5 billions of dollars, which equaled to four-fifths of the entire company's market value, in back tax payments (Ahn, 2014, pp. 21-22). There were other changes in media ownership and it was obvious that these changes favored government friendly corporations; for example, Berat Albayrak, the son- 
in-law of Recep Tayyip Erdoğan, became the CEO of Çalık Group, which incorporated Turkuvaz Media Group and Çalık Group gained power in the sector (May, 2013).

Journalists are under judicial suppression in Turkey as well. In 2008, many nationalist journalists were arrested and imprisoned in relation to the Ergenekon trials. These journalists were accused of getting involved in illegal activities to overthrow the government. They were investigated and arrested depending on phone taping and reports of anonymous witnesses (Akser \& Baybars-Hawks, 2012, p. 314). At the moment Can Dündar, the editor-in-chief of the opposition Cumhuriyet newspaper, and Erdem Gul, the paper's Ankara bureau chief, are imprisoned with the accusation of spying and "divulging state secrets" (The Guardian, 2015). Turkey has a high number of jailed journalists and this fact seems to 'teach' journalists how to self-censor themselves (May, 2013:300). Even if they do not get arrested, Turkish journalists know that they face the risk of being sued as well. In 2011, Freedom House reported that there are more than 4000 lawsuits pending against journalists in Turkey. All these factors have led to the establishment of an intimidating media autocracy and a hostile, even dangerous environment that deterred journalists from reporting opposing views (Ahn, 2014, pp. 20, 24).

Another pressure practiced on Turkish media is the press list that is released by prime minister's press bureau. This list includes journalists that are considered as 'safe and friendly' and excludes the critical ones. Needless to say, the ones in the list are given direct access to the prime minister and the government authorities and the others are not. This practice leads to accreditation discrimination among journalists (Akser \& Baybars-Hawks, 2012, 314). Critical journalists face the risk of losing their job as well due to the fact that the firings of journalists are not exceptional in today's Turkey. For example, all the staff of 'NTV Tarih', a history magazine, was dismissed and the magazine was closed down after they published a special 'Gezi edition' (Ahn, 2014, pp. 21, 22, 26).

Taking all these factors into consideration, it is not hard to understand why journalists keep their voices down, suppress news or change their tones and angles. Wiretappings that covered conversations between Recep Tayyip Erdoğan and directors and editors in the media sector were leaked to the public; these leaks and self-reports of journalists and editors revealed that they are being instructed regularly by the government agencies and are afraid to report opposing views (Ahn, 2014, p. 25). It is also not surprising to see how the activists in the sample of this study portray and criticize the media.

In line with the criticism of the Turkish media, a large group of activists indicated that social media provided people who were desperate with a tool of expression, pointed to the factors that limited their actions and highlighted the significance of the safety that social media provided them with. After Gezi protests, people learnt that they can face serious risks if they take part in a protest. According to Turkish human rights organization eight people died, 8163 were injured, 5300 were arrested, 160 were kept in long-term detention and many were arbitrarily detained without charge for hours during the protests. That's why people felt safer online. An activist put forward this idea with the following statement:

It is easier and safer. At least it used to be. When you talk about something on TV or join a protest meeting, you can get arrested and brought to court, with the risk of being sentenced to serving time in prison, but if you tweet it, you are on the safe side... oh, again, you used to be.

This comment is a consequence of Law No. 5651, which envisages harsh measures against freedom of expression on the internet with the justification of prevention of crime and protection of national security, public order, public health, life, property, and the esteem and honor of individuals against defamation on the internet. Amendments to Law 5651 were passed in 2014 partly due to the role that social media played during and after Gezi protests in 2013 and the related measures became even harsher (Akgül \& Kırlıdoğ, 2015, p. 11). As a result, Turkish people 'learnt' that they can get punished because of their actions on the social media; especially after witnessing Twitter arrests. People were arrested because they actively used Twitter to spread information during Gezi protests (Nilgün, 2015, p.13). 
The fact that the control of the government on the judicial system has increased dramatically due to laws that were passed by AKP in the past decade has also added to this fear atmosphere. At the moment, all judicial candidates have to take an oral exam carried out by the Ministry of Justice, 14 of the total 17 members of the Turkish Constitutional Court are appointed by the President from a selected pool and all 16 seats of the Supreme Board of Judges and Prosecutors (HSYK), which is the sole body to appoint and promote judges and prosecutors, are filled by the ministry's chosen candidates. In addition, HSYK is led by the minister of justice and the undersecretary of the Ministry of Justice as board members, the minister of justice has sole supervisory power over HSYK and can manage composition of all three chambers of the board or initiate disciplinary procedures for HSYK members. After the corruption and bribery news involving ministers, the prime minister and progovernment businessmen broke on December 17, 2013, hundreds of prosecutors and judges were reassigned, which embodied the power that the government has over the judicial system (Ahn, 2014, pp. 30, 31, 34). It is not unusual for the former Prime Minister, current President Recep Tayyip Erdoğan to publicly announce that he expects prosecutors to take action about a specific issue. He once announced that judges should take off their robes and "start doing politics" (Ahn, 2014, p.36). This statement answers why people with opposing views fear that the due process is distorted and the judicial system serves the governments' interests.

Comments of 131 activists focused on the role social media plays in creating awareness, management of protests and creating positive publicity for the activists and the cause itself. A large line of comments in this category praised how social networking sites could be used to reach more people, spread information and to create awareness. Some of these comments are:

Now we can get to know information more easily, faster and in every detail. Nothing is kept as secret anymore. So we take our guards, see both sides of an event and get conscious about what happens in the world and in our country, join the groups we support and show our opposition more and make our voices louder.

... People share their comments and perceptions and what we need to do, what digital social media should teach people is that 'see what is going on, don't mind the comment, think, filter and interpret it yourself'. This is a 'beware!' side of digital technologies and the internet.

In civil movements in Turkey, social media was used to show the world what was going on, an alternative to mass media was created. This has united many occupational groups, people of different ages and ideas that have never got involved in a protest before. Recep Tayyip Erdoğan's allergy to social media can be considered as proof of its strength.

Managerial purposes mentioned by the activists covered organization, coordination, mobilization of activists and providing morale support. Attracting attention, keeping events on the agenda of the country, generating national and international support were also among the main purposes that social networking sites served according to these activists. It should be noted here that the role social media plays in creating awareness, management of protests and creating positive publicity for the activists and the cause itself were reported by activists from Egypt, Latin America, the United States and Scotland as mentioned previously (Ghannam, 2011; Gerbaudo, 2012; Harlow \& Harp, 2012; Harp, Bachmann \& Guo, 2012; Hemmi \& Crowther, 2013 ). However, it was interesting to see that only 131 activists in the sample commented on these purposes despite the fact that they are emphasized to a great extent in both theoretical and applied studies in the field.

With regard to Turkish activists' perceptions on the limitations of digital activism in Turkey, it was found out that 243 activists voiced limitations related to the political environment in Turkey. The government itself was criticized intensely by the activists with imposing its rules on the society and never agreeing opposition, not respecting fundamental rights and freedoms, caring about their own interests only, manipulating religious feelings and having a dictatorial approach. Oppression and prohibitions, a lack of democracy, and the former Prime Minister, current President Recep Tayyip Erdoğan were pointed as the main limitations of digital activism by some of the activists in this group. Another line of comments in this category focused on surveillance, control and manipulation of the 
internet by the government as a major limitation. The activists stated concerns about surveillance with statements such as 'illegal VPN tracking', 'surveillance on individuals' accounts' and 'the Presidency of Communication'. The fact that the government could block access to social networking sites and weaken digital activism efforts was verbalized and the government was criticized for maintaining an oppressive hegemony on the internet, censoring any digital effort that would conflict their interests and generating counter propaganda with the aim of emptying the rhetoric of activism efforts via the creation of fake accounts that are, in fact, related to the government. In line with these comments, 65 activists stated a disbelief in the judicial system of Turkey, accused jurisdiction with being under control of the government and serving its interests and that reported that because of these factors, a fear atmosphere, which deterred people from getting involved in digital activism, was created. Activists in this group enounced their disbelief in the judicial system, highlighted the fact that many people were arrested at a moment's notice and some were even sentenced because of what they shared on social media. An activist elaborated on the problem of surveillance and coactions by the government and the resulting fear atmosphere with the following words:

\begin{abstract}
E-revolution requires a system; an infrastructure let me say, which beats the 'tracking system' of the government; if it is to be a revolution, a real change. In a country where all protests are published on Facebook, which is closely watched and controlled by the government and where Twitter accounts can be suspended within matter of minutes, this is not possible. So I personally believe internet and digital activism is a great and very effective tool to gather people who share the same views and ideas and allow them to form a platform but when it comes to making a real change, it is not safe nor an enabling ground for activism...Smart phones are a big help but most activists do not use smart phones, as they are easier to track down due to their 'registered' technologies and programs. If they want to do anything further that will actually lead to a change, they have to find another platform that is not controlled by the government. Otherwise it is nothing but 'governmentallowed-activism', like a child playing in the sand with his/her mother watching.
\end{abstract}

The political and judicial limitations self-reported by the activists in the sample explain and complement their perceptions on the potential uses of digital technologies. Under these circumstances, it becomes more evident why Turkish activists appreciate easy, fast and safe communication SNS provides them with, convenience and potential reach of digital activism, how the interactive nature of SNS unites people and how it provides people with a tool for free expression. It is clear that they feel a desire for social change but do not feel able or safe but trapped in a politically and judicially limiting environment. That's why easy, fast and safe correspondence is important for them when they feel the need because they cannot trust any other communication channels in this respect. They also need a medium where they can express their ideas freely due to the status of current Turkish media. They know that they need more people who think like them and support them to initiate change; that's where the potential of SNS for reaching potential supporters easily, raising awareness and creating positive publicity comes into play. They praise the role of SNS in creating an interactive environment, creating unity and managing protests because they experienced first hand that SNS could make a significant contribution in this respect during Gezi protests.

The comments made by a total of 64 activists centered on Turkish people and Turkish culture. Turkish people were accused of being indifferent, ignorant, apolitical and inactive. They were also criticized for not being critical minded and literate enough to engage in digital activism. Some of the comments pointed to the lack of a discussion culture among Turkish people as a major obstacle. Turkish culture was critiqued with phrases such as 'conservative', 'feudal structure', 'social differentiation', 'culture of hatred' and 'parental pressure'. These activists indicated that the cultural norms that Turkish people are born into deter them from activism efforts. Example statements that are related to criticism of Turkish people and culture are included below:

The half of the public who are ignorant, never question anything and prefer to stay like that. People's self-indulgence and the tension and intolerance we experience at work and home made us all Clark Kent in the morning and Superman at night. 
The fact that people support parties as if they support football teams. They don't read, research, question; but follow a leader just like a sheep herd.

The phrase 'sheep herd' is one that has been used very frequently by people who do not support the practices of AKP, which has been ruling Turkey since 2002, to describe the other half of the population who votes for and supports the party. The phrase has become a symbol of the extent to which the public has been polarized. Considering that the activists in the sample of the present research were the ones who have not voted for AKP, it is not hard to see that these criticism of Turkish people and culture was a reflection of this group's disappointment with the other half of the public who voted the present government and the culture that shapes the thought patterns of these people. It was also a means of calling the legitimacy of AKP into question by implying that its voters were ignorant, indifferent, uneducated and unwise. One of the main slogans during Gezi protests 'disproportionate intelligence' was a reflection of this disappointment and an attempt to show that AKP, which was voted by a 'sheep herd' was not a legitimate government.

\section{DISCUSSION}

The results of this study confirmed previous research studies carried out with activists of different cultural origins. Turkish activists self-reported that they perceive SNS as convenient and useful tools that can be utilized for activism purposes. More than five sixth of the activists in the sample indicated that they appreciated SNS for providing a fertile ground for activism and just under half of the activists drew attention to the potential of SNS for managerial purposes, for awareness raising and for creating positive publicity for the cause and the activists. The comments of Turkish activists overlapped with the comments of activists from China, Latin America, the United States, Scotland and Egypt in this sense. However, the third line of comments that focused on the maintenance of polyvocality illustrated the culture-bound nature of digital activism. The fact that more than one third of Turkish activists highlighted the significance of the role that SNS played in providing an alternative media through which people could express themselves freely without feeling afraid of potential consequences and overcome political, social and legal barriers pointed to a broad based concern about a lack of democracy and fear of surveillance among the activists. It should be stated here that these concerns were voiced by the activists from China and Egypt as intensely as in Turkey. There is no doubt that the intersection point of these countries is the activists' concerns about lack of democracy. The fact that the top challenge self-reported by American activists was lack of time and the lack of access to affordable internet was the most significant obstacle that was expressed by Brazilian activists while activists in Turkey, China and Egypt were so worried about lack of democracy and surveillance illustrates how the political, social and economical parameters in a country can have an effect on digital activism.

Turkish activists' perceptions on the limitations of SNS supported these findings. The political environment was named as the most important limitation. Key terms listed by the activists were the government, oppression, lack of democracy and Recep Tayyip Erdoğan. Likewise, activists in this sample named surveillance, control and manipulation of the internet by the government and the judicial system, which they describe as one that serves the governments' interests as limitations to digital activism as they witnessed arrests of digital activists during and after Gezi Park protests and experienced that the fear atmosphere that was created impeded digital activism efforts. Social criticism of Turkish people as an obstacle to digital activism was a reflection of activists' disappointment with the public that supported the government. Not having succeeded in persuading and gaining the support of this section of the public during and after Gezi Park protests was the main reason why political change could not be triggered. Therefore, it is quite normal that the activists in this study regard ignorance, inactiveness and low educational level of Turkish people as limitations of digital activism.

\section{REFERENCES}

Ahn, J. S. J. (2014). Turkey's Unraveling Democracy: Reversing Course from Democratic Consolidation to Democratic Backsliding. CMC Senior Theses, Claremont McKenna College, USA. Akgül, M. \& Kırlıdoğ, M. (2015). Internet Censorship in Turkey. Internet Policy Review, 4(2), 1-22. 
Akser, M. \& Baybars-Hawks, B. (2012). Media and Democracy in Turkey: Toward a Model of Neoliberal Media Autocracy. Middle East Journal of Culture and Communication, 5, 302-321

Amin, R. (2009-2010). The Empire Strikes Back: Social Media Uprisings and the Future of Cyber Activism. Harvard Kennedy School Review, 10, 64-66.

Bakardjieva, M., Svensson, J., \& Skoric, M. M. (2012). Digital Citizenship and Activism: Questions of Power and Participation Online. JeDEM , 4(1), 1-5.

Banks, M. J. (2014). The Picket Line Online: Creative Labor, Digital Activism, and the 2007-2008 Writers Guild of Amerika Strike, Popular Communication. The International Journal of Media and Culture, 8(1), 20-33.

Baraković, V. (2011). Facebook Revolutions: The Case of Bosnia and Herzegovina, Acta Universitatis Sapientiae. Social Analysis, 1(2), 194-205.

Borrero, J. D., Yousafzai, S. Javed, U., \& Page, K. L. (2014). Perceived Value of Social Networking Sites (SNS) in Students' Expressive Participation in Social Movements. Journal of Research in Interactive Marketing, 8(1), 56-78.

Boykoff, M. T. (2012). Digitally Enabled Social Change: Activism in the Internet Age. Contemporary Sociology, 41(4), 486-487.

Castells, M. (2009).Communication Power. Oxford: Oxford University Press.

Christensen H. S. (2011). Political Activities on the Internet: Slacktivism or Political Participation by Other Means. First Monday, 16(2).

Christensen H. S. (2012). Simply Slactivism? Internet Participation in Finland. JeDEM, 4(1), 1-23.

Cho, J. Y., \& Lee, E. H. (2014). Reducing Confusion about Grounded Theory and Qualitative Content Analysis: Similarities and Differences. The Qualitative Report, 19(64). 1-20.

Gerbaudo, P. (2012). Tweets and the Streets: Social Media and Contemporary Activism. London: Pluto Press.

Ghannam, J. (2011). Social Media in the Arab World: Leading up to the Uprisings of 2011. Center for International Media Assistance. Date of access: September 23, 2014, http://cima.ned.org/sites/default/files/CIMA-Arab_Social_Media-Report-10-25-11.pdf

Harlow, S. \& Harp. D. (2012). Collective Action on The Web. Information, Communication \& Society, 15(2), 196-216.

Harp, D., Bachmann, I., \& Guo, L. (2012). The Whole Online World is Watching: Profiling Social Networking Sites and Activists in China, Latin America, and the United States. International Journal of Communication, 6, 298-321.

Hemmi, A. \& Crowther, J. (2013) Learning Environmental Activism through Social Networking Sites?. The Journal of Contemporary Community Education Practice Theory. 4(1), 1-7.

Kaya, R. \& Çakmur, B. (2010). Politics and the Mass Media in Turkey. Turkish Studies, 11(4), 521537.

Lunceford, B. (2012). The Rhetoric of the Web: The Rhetoric of the Streets Revisited Again.

Communication Law Review, 12(1), 40-55.

May, Asena. (2013). Twelve Sycamore Trees Have Set the Limits on Turkish PM Erdoğan's Power.

American Foreign Policy Interests, 35, 298-302.

Micó, J.L., \& Ripollés, A. C. (2014). Politicalactivism Online: Organization and Media Relations in the Case of 15M in Spain. Information, Communication \& Society, 17(7), 858-871.

Morozov, E. (2009). The Brave New World of Slacktivism. Foreign Policy. Date of access: November 22, 2011, http://neteffect. Foreignpolicy .com/posts/ $2009 / 05 / 19 /$ the brave new world of slacktivism,

Muhammad, E. (2001). Hactivisim. Techno.Fem, 74, 75-76.

Murdoch, S. (2010). Destructive Activism: The Double-Edged Sword of Digital Tactics., M. Joyce (Ed.), Digital Activism Decoded (137-148). New York: iDebate Press. Date of access: December 11, 2014, http://www.cl. cam.ac.uk/ sjm217 /papers/ digiact 10 destructive.pdf.

Newsom, V. A., \& Lengel, L. (2012). Arab Women, Social Media, and the Arab Spring: Applying the Framework of Digital Reflexivity to Analyze Gender and Online Activism. Journal of International Women's Studies, 13(4), 31-45.

Nilgün, M. (2015). Cyberactivism 2.0: Determining Social Media Usage in New Social MovementsTwitter and Gezi Resistance in Turkey, MA Thesis, Universiteit Van Amstersdam, the Netherlands. 
Norman, J. (2001). Cyber Activists Target Lufthansa. Information Management \& Computer Security, 9(5), 250-251.

Putnam, R. D. (2000). Bowling Alone: The Collapse and Revival of American Community. New York: Simon \& Schuster.

Schulman, S.W. (2009). The Case against Mass E-Mails: Perverse Incentives and Low Quality Public Participation in US Federal Rulemaking. Policy \& Internet, 1(1), 23-53.

Shah, N. (2013). Citizen Action in the Time of the Network. Development and Change, 44(3), 665681.

Shirky, C. 2008. Here Comes Everybody: The Power of Organizing without Organizations. New York: Penguin Books.

Sivitanides, M., \& Shah, V. (2011). The Era of Digital Activism, Education Special Interest Group of the AITP, CONISAR Proceedings, Date of access: November 2, 2014, http://proc.conisar.org/2011/pdf/1842.pdf.

Štětka, V., \& Mazák, J. (2014). Whither Slacktivism? Political Engagement and Social Media Use in the 2013 Czech Parliamentary Elections. Cyberpsychology: Journal of Psychosocial Research on Cyberspace, 8(3), 1-17.

Şener, G. (2014). Social Media as a Field of Social Struggle. Journal of Media Critiques, 2 (Special Issue on Social Media and Network Society), 185-198.

The Guardian. (2015). Turkish journalists charged over claim that secret services armed Syrian rebels. Date of access: January 25, 2016, http://www.theguardian.com/world/2015/nov/27/turkishjournalists-charged-over-claim-that-secret-services-armed-syrian-rebels. 